\title{
Bioaccumulation and Effects of Aluminium on Plant Growth in Three Culture Plants Species
}

\author{
BOGDAN-STEFAN NEGREANU-PIRJ OL ${ }^{1}$, TICUTA NEGREANU-PIRJ OL ${ }^{1 *}$, RODICA SIRBU ${ }^{1}$, DAN RAZVAN POPOVICIU² \\ ${ }^{1}$ Ovidius University of Constanta, Faculty of Pharmacy, 1 University Alley, Campus, Corp B, 900470, Constanta, Romania \\ ${ }^{2}$ Ovidius University of Constanta, Faculty of Natural Sciences and Agricultural Sciences, 1, University Alley, Campus, Corp B, \\ 900470, Constanta, Romania
}

\begin{abstract}
Aluminium toxicity is one of the major factors that limit plant growth and development in many acid soils, by multiple, and still poorly understood mechanisms. In this paper, the aluminium content determinations were done through atomic absorption spectrometrymethod, on seedlings of three culture plants, Helianthus annuus L. (sunflower), Sinapis alba L. (white mustard) and Triticum aestivum L. (wheat), grown in hydroponic conditions with different aluminium concentrations (50, 100 and $250 \mathrm{mg} / \mathrm{kg}$ ) expose. AAS data were correlated with biometrical determinations (shoot length and dry biomass) and leaf pigments concentration assessment. Results emphasize that none of the selected species accumulates aluminium in aboveground organs such as shoots and leaves, indicating that root exclusion and/or sequestration are the strategies employed by all three species for limiting aluminium toxicity. In all three studied species, both average shoot length and dry biomass tended to be lower at higher aluminium concentration. Due to high variations among seedlings grown at the same aluminium concentration expose, these differences are not statistically significant. In sunflower seedlings, chlorophyll a and carotenoids had maximum values at the highest aluminium concentration ( $250 \mathrm{mg} / \mathrm{kg}$ ), while chlorophyll b was more abundant at $100 \mathrm{mg} / \mathrm{kg}$. In mustard, all pigments had their maximum concentrations at $100 \mathrm{mg} / \mathrm{kg}$, while in wheat, an aluminium concentration increase progressively lead to a drop in pigments concentration.
\end{abstract}

Keywords: bioaccumulation, aluminium, Helianthus annuus L., Sinapis alba L., Triticum aestivum L., phytotoxicity

Heavy metal toxicity to plants, livestock and humans is a growing problem, due to various industrial activities. Plants can adapt to high metal concentration in soils by several mechanisms, such as root exclusion (limiting uptake from soil), root sequestration (limiting translocation to sensitive tissues) or bioaccumulation in metal-tolerant tissues. While phytoaccumulation may have important applications in bioremediation and biomining, knowing that this metal accumulation in crop plants is hazardous for potential consumers [1-4].

Aluminium is the most abundant metallic element present in majority soils, in low concentrations. At high concentrations, it becomes toxic. It is not usually an essential nutrient, but it can enhance plant growth, under certain specific conditions. It occurs naturally in soils as minerals such as, alumino-silicates (feldspars, micas, kaolin etc.), oxides and hydroxides, which are relatively abundant, average concentrations, amount to $70,000 \mathrm{mg} /$ $\mathrm{kg}$. However, only a small part becomes soluble and, thus, bioavailable (a lower $\mathrm{pH}$ leads to more aluminium ions in soil solution) [5]. Depending on soil acidity and plant species, phytotoxic effects can occur at as low as 2-3 mg/ $\mathrm{kg}$ [6]. Aluminium toxicity mechanisms are varied. Inhibition of water absorption, uptake of some essential nutrients (i.e., nitrogen, phosphorus, $\mathrm{Ca}, \mathrm{Mg}, \mathrm{K}, \mathrm{Mn}$ ), was documented in various plant species and, obviously, lead to a decrease in plant growth and productivity. Aluminium is known to inhibit the proper development of lateral roots, lower root respiration, thicken root cell walls and damage cortical tissue thus also limiting water and nutrient uptake $[5,6]$.

Aluminium has been reported to affect normal development of chloroplast thylacoids, which, in turn, lower the amount of photosynthetic pigments [5]. Furthermore, interference with magnesium uptake also affects the normal synthesis of chlorophylls. Among plants that are sensitive to magnesium uptake disorders are various Poaceae species, such as Zea mays L. and Lolium multiflorum Lam. $[5,6]$.

This becomes a major problem for agricultural crops, where productivity and lack of toxicity to consumers are crucial. Studies on various herbaceous species throughout the world have shown that natural aluminium accumulation is rare and most plant species behave as excluders, limiting radicular absorption of aluminium ions. The main mechanism for limiting aluminium uptake is the radicular secretion of acids (oxalate, citrate) [7]. The most common values are below $100-200 \mathrm{mg} / \mathrm{kg}[5,7,8]$. Regarding Sinapis alba L. species, for instance, other experiments, determined aluminium concentrations of 10 $20 \mathrm{mg} / \mathrm{kg}$ in stems and leaves, even when grown on aluminium-polluted soils [9].

It should be noted that, while in most plants, aboveground organs have low aluminium concentration, in some species values can be relatively high in roots and underground stems (if present) [10].

\section{Experimental part}

Three common crop species were selected for this experiment: Helianthus annuusL. (sunflower), Sinapis alba L. (white mustard) and Triticum aestivum L. (wheat).

Seedlings of each species were collected 10 days after germination and transfered to hydroponically Knop's solution with $\mathrm{AlCl}_{3}[11,12]$ added to 50,100, and $250 \mathrm{mg} /$ $\mathrm{kg}$ aluminium concentrations. Determinations were done after another 10 days from seedling transfer.

A part of the seedlings, cut into small-size pieces and has been dried at $80^{\circ} \mathrm{C}$ for three days. A quantity of $0.25 \mathrm{~g}$ of each dried sample were left digesting overnight in $5 \mathrm{~mL}$

*email: ticuta_np@yahoo.com 
$\mathrm{HNO}_{3} 67 \%$ concentration, boiled for one hour at $150^{\circ} \mathrm{C}$, supplemented with $2 \mathrm{~mL} \mathrm{H}_{2} \mathrm{O}_{2} 30 \%$ concentration and boiled again for 2 hours. The obtained solutions were made up in a $50 \mathrm{~mL}$ beaker with distilled water (also adding $2 \%$ $\mathrm{NH}_{4} \mathrm{Cl}$ and $0.5 \% \mathrm{CaCl}_{2}$ ) [13-15]. Aluminium content was determined thorugh atomic absorption spectrometry method, using HR-CS ContrAA 700 apparatus, Analytik J ena AG, Germany, with acetylene-nitrous oxide flame, at 396 $\mathrm{nm}$ wavelength [16-18]. Aluminium concentration present in plant tissues has been calculated and expressed as $\mathrm{mg} /$ $\mathrm{kg}$.

For determining the phytotoxic effect on seedlings, shoot length, biomass and photosynthetic pigments were used as indicators.

Seedlings of each species (more than 10 for each batch, randomly chosen) were measured and weighed. A quantity of $0.1 \mathrm{~g}$ of plant leaves were grounded in $10 \mathrm{~mL} 80 \%$ acetone, filtered and optical absorbance was determined using a WPA S106 UV-Vis spectrophotometer, at $470 \mathrm{~nm}$, $647 \mathrm{~nm}$ and $663 \mathrm{~nm}$ wavelengths. Absorbance values were used to determine chlorophyll $a$, chlorophyll $b$ and carotenoid pigments (xantophyll and carotin) content, according to specific equations $[19,20]$.

Pearson's correlation coefficients were used to indicate liks between variations of the different parameters measured (a value close to $-/+1$ indicates a strong correlation) [21].

A widely used index of metal accumulation is the Biological Accumulation Coefficient (BAC), calculated as a ratio of metal concentration in shoots and soil (or, in this case, hydroponic solution). A value above 1 indicates accumulation, while values below 1 indicate various levels of exclusion [17, 18, 22, 23]. Plants with a BAC below 0.01 are considered as non-accumulating and at $B A C$ between $0.01-0.1$, plants are weak accumulators [24]. However, defining BAC in a hydroponic context is difficult, because a concentration in dry plant mass cannot be compared to metal concentration in aqueous solution.

\section{Results and discussions}

Tissular aluminium concentration for plants in each hydroponic batch is shown in figure $1(0.0055 \mathrm{mg} / \mathrm{L}$ being the minimal limit of detection).

Biometrical data (shoot length and biomass of seedlings grown at different aluminium concentrations are shown in figure 2 and figure 3 . Also, in figure 4 is presented the concentration of the three analyzed pigments in the leaves of plant seedlings.

Statistical correlations between aluminium concentrations in hydroponic solutions and plant parameters measured are emphasized in table 1.

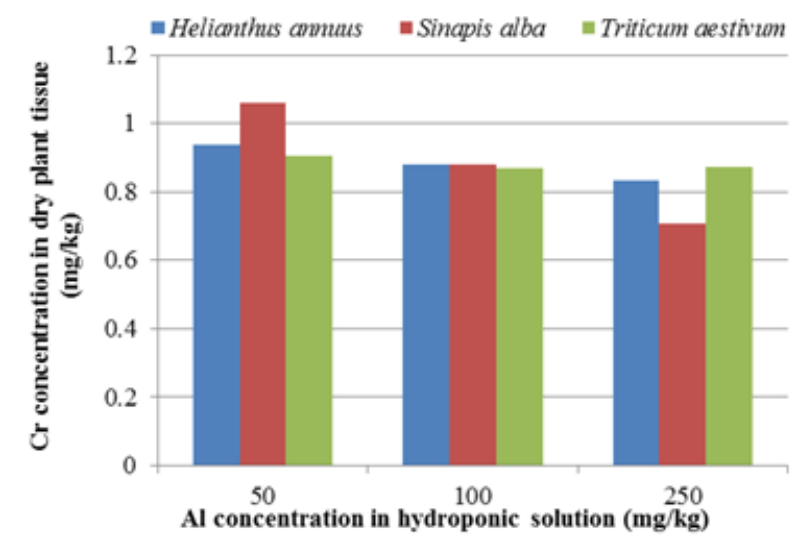

Fig. 1. Aluminium concentration in plant tissue $(\mathrm{mg} / \mathrm{kg}$ dry weight; average values)

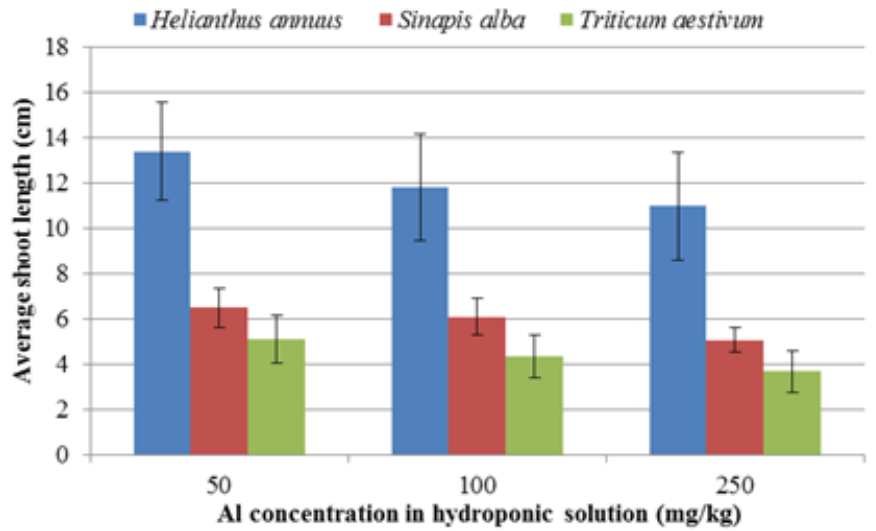

Fig. 2. Shoot length of seedlings $(\mathrm{cm})$

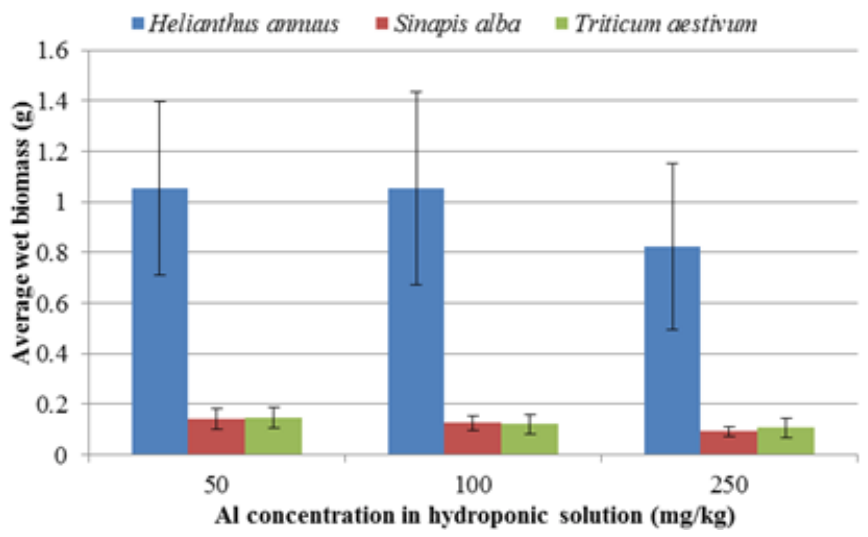

Fig. 3. Biomass (wet) of plant seedlings ( $g$ )

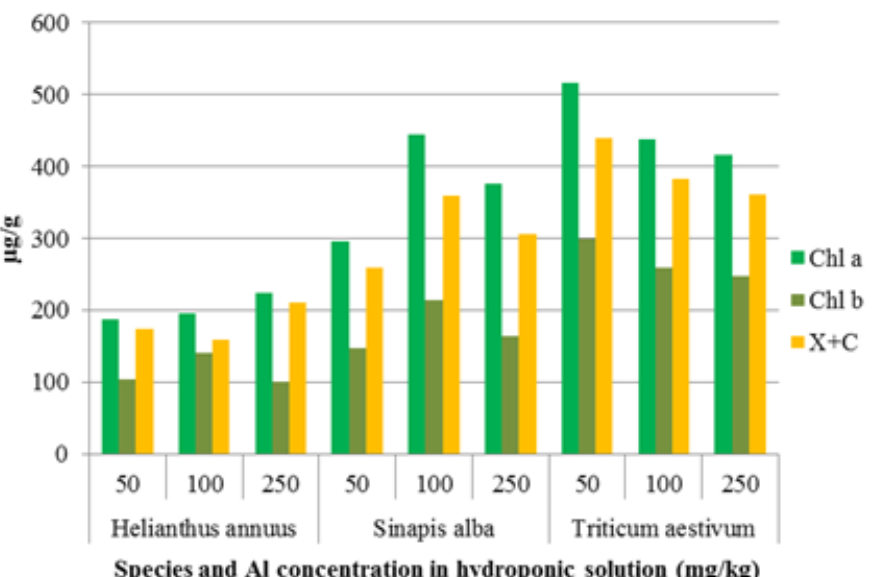

Fig. 4. Photosynthetic pigments (chlorophylls and carotenoids) concentrations in plant seedlings ( $\mu \mathrm{g} / \mathrm{g}$ total biomass)

Table 1

PEARSON'S CORRELATION COEFFICIENTS BETWEEN ALUMINIUM CONCENTRATION AND OTHER PARAMETERS DETERMINED FOR THE THREE VEGETAL SPECIES

\begin{tabular}{|l|l|l|l|}
\hline Parameter & $\begin{array}{l}\text { Helianthus } \\
\text { annuus L. }\end{array}$ & $\begin{array}{l}\text { Sinapsis } \\
\text { alba L. }\end{array}$ & $\begin{array}{l}\text { Triticum } \\
\text { aestivum L. }\end{array}$ \\
\hline $\begin{array}{l}\text { Tissular aluminium } \\
\text { concentration }\end{array}$ & -0.94 & -0.96 & -0.62 \\
\hline Shoot length & -0.90 & -1 & -0.96 \\
\hline Biomass & -0.97 & -0.99 & -0.91 \\
\hline Chlorophyll $a$ & 1 & 0.28 & -0.82 \\
\hline Chlorophyll b & -0.35 & -0.05 & -0.83 \\
\hline Carotenoids & 0.86 & 0.20 & -0.86 \\
\hline
\end{tabular}


Tissular aluminium concentrations were extremely low in all analyzed samples.

Concerning biological accumulation coefficients, while, in theory, values of $0.01-0.02$ were found in all three species in $50 \mathrm{mg} / \mathrm{kg}$ batches, the values should be corrected by reporting tissular aluminium to total (wet) biomass. In this case, all studied plants should be considered as nonaccumulating.

Pearson's correlations indicate that metal accumulation decreased when aluminium concentration in the environment increased. Correlations between tissular aluminium and aluminium concentration in hydroponic solutions were stronglynegative in sunflow er and mustard and weaker in wheat. This negative feedback is probably due to root inhibition.

As stated above, aluminium is known to affect normal rootgrowth and functionality and lower water and mineral uptake. This way, aluminium phytotoxicity would limit its own absorption from soil. Regarding aluminium presence effect on plant growth, there were differences among average shoot length and biomass among batches. The least affected were sunflower plants, with a $17.94 \%$ difference in length and $22.05 \%$ in biomass among extreme aluminium concentrations (50 and $250 \mathrm{mg} / \mathrm{kg}$; fig. 5). It should be noted that variations among plants in the same batch were also observed. Standard deviation values indicate that, while differences between average shoot length and biomass were noticeable, they cannot be considered as statistically significant (fig. 2 and fig. 3).

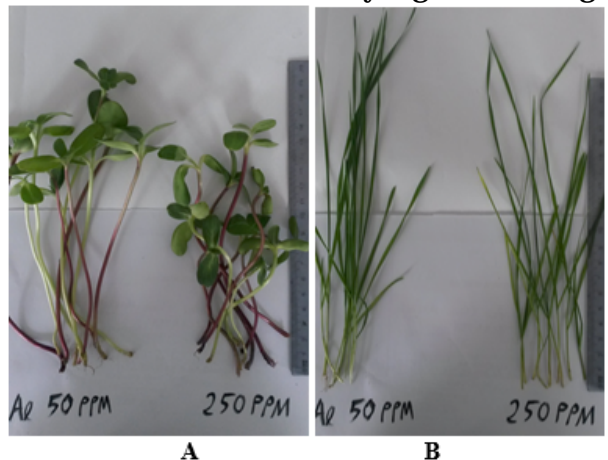

Fig. 5. Comparative growth of seedlings grown in 50 and $250 \mathrm{mg} / \mathrm{kg}$ aluminium concentration: (A) Helianthus annuus L.; (B) Triticum aestivum L.; (C) Sinapis alba L.

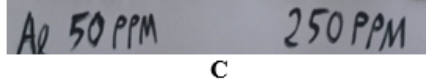

For photosynthetic pigments content, the results were different among studied species. A higher aluminium concentration inhibited chlorophylls and carotenoids synthesis in wheat, stimulated chlorophyll $a$ and carotenoids synthesis in sunflower and had no correlation to pigments concentration in mustard. Aluminium interference with proper synthesis of chlorophyll pigments and development of chloroplasts in many species, including some other common Poaceae, which would explain the more pronounced effect on pigments amounts in wheat seedlings $[5,6]$.

\section{Conclusions}

Considering AAS determinations results on tissular aluminium levels, all of the three studied culture plants species (sunflower, mustard and wheat) behaved as aluminium excluders, with concentrations mostly below $1 \mathrm{mg} / \mathrm{kg}$.

Tissular aluminium levels decreased at higher hydroponic aluminium concentrations. A higher aluminium concentration in hydroponic solutions led to a decrease in average shoot length and weight of seedlings in all three species, however, this decrease was not a statistically significant one.

Regarding photosynthetic pigments, their synthesis was enhanced in sunflower, but decreased in wheat. Variations referring pigment levels in mustard cannot be linked to aluminium concentration.

As a final conclusion, at selected aluminium concentrations $(50-250 \mathrm{mg} / \mathrm{kg})$ for vegetal raw expose, no metal accumulation occurs in the selected culture plants. However, productivity can be affected.

\section{References}

1. RASCIO, N., NAVARIIIZZO, F. Plant Sci., 180, 2011, p. 169.

2. TANG, Y.T., DENG, T.H.B., WU, Q.H., WANG, S.Z., QIU, R.L., WEI, Z.B., GUO, X.F., WU, Q.T., LEI, M., CHEN, T.B., ECHEVARRIA, G., STERCKEMAN, T., SIMONNOT, M.O., MOREL J.L., Pedosphere, 22, no. 4, 2012, p. 470.

3. NICULAE, G., BADEA, N., MEGHEA, A., OPREA, O., LACATUSU, I., Photochemistry and Photobiology, 89(5), 2013, p.1085

34. GINGASU, D., OPREA, O., MINDRU, I., CULITA, D.C., PATRON, L., Digest J ournal of Nanomaterials and Biostructures, 6(3), 2011, p. 1215 5. MIYASAKA, S.C., HUE, N.V., DUNN, M.A. Aluminium. Handbook of Plant Nutrition (Eds. A.V. Barker, D.J. Pilbeam), CRC Press, Boca Raton, 2006, p. 567.

6. ROUT, G., SAMANTARAY, S., DAS, P., Agronomie, 21, no. 1, 2001, p. 3.

7. WATANABE, T., OSAKI, M., Commun. Soil Sci. Plant. Anal., 33, no. 78, 2002, p. 1247.

8. GENISEL, M., TURK, H., ERDAL, S., SISMAN, T., DEMIR, Y., KOHNEHSHAHRI, S.M., KIZILKAYA, M., J. Environ. Prot. Ecol., 16, no. 4, 2015, p. 1297.

9. KOWALSKA, J., ASZTEMBORSKA, M., BYSTRZEJ EWSKAPIOTROWSKA, G., FLIS, P., 15th ICHMET Proceedings, 2010, p. 405.

10. MOREIRA DA SILVA, M., ANÍBAL, J., DUARTE, D., CHÍCHARO, L., J. Environ. Prot. Ecol., 16, no. 4, 2015, p. 1468.

11. MOHR, H., SCHOPFER P., Plant physiology. Springer, Berlin, 1995. 12. BADORA, A., Pol. J. Environ. Stud., 11, 2002, p. 109.

13. POPOVICIU, D.R., NEGREANU-PIRJ OL, T., SIRBU, R., Journal of Science and Arts, Year 18, 42, no. 1, 2018, p. 211.

14.NEGREANU-PIRJ OL, B.-S., NEGREANU-PIRJ OL, T., POPOVICIU, D.R., Rev. Chim. (Bucharest), 68, no. 11, 2017, p. 2488.

15.POPOVICIU, D.R., NEGREANU-PIRJ OL, B.-S., FAGARAS, M., DUZGUNES, E., NEGREANU-PIRJOL, T., J. Environ. Prot. Ecol., 18 (1), 2017, p. 22.

16.SHANKER, A.K., DJANAGUIRAMAN, M., SUDHAGAR, R., CHANDRASHEKAR, C.N., PATHMANABHAN, G., PlantSci., 166, 2004, p. 1035.

17. POPOVICIU, D.R., NEGREANU-PIRJ OL, T., BERCU, R., Rev. Chim. (Bucharest), 67, no. 4, 2016, p. 670.

18. POPOVICIU, D.R., NEGREANU-PIRJ OL, T., MICLAUS, L.S., Rev. Chim. (Bucharest), 68, no. 1, 2017, p. 40.

19. MESI (DIZDARI), A., KOPLIKU, D., J. Environ. Prot. Ecol., 17, no. 1, 2016, p. 297.

20. LICHTENTHALER, H.K., BUSCHMANN, C., Curr. Protoc. Food Anal. Chem., 2001, F4.3.1.

21. PAULSON, D.S., Biostatistics and Microbiology: A survival manual. Springer, New York, 2008, 216 pp.

22. NAZIR, A., MALIK, R.N., AJAIB, M., KHAN, N., SIDDIQUI, M.F., Pak. J. Bot., 43, no. 4, 2011, p. 1925.

23. OBASI, N.A., AKUBUGW O, E.I., KALU, K.M., UGBOGU, O.C., Int. J. Curr. Biochem. Res., 1, no. 4, 2013, p. 16.

24. SEKABIRA, K., ORYEM-ORIGA, H., MUTUMBA, G., KAKUDIDI, E., BASAMBA, T.A., Int. J. Plant Physiol. Biochem., 3, no. 8, 2011, p. 133.

Manuscript received: 4.05 .2018 